\title{
KURSY HISTORII POLSKI DLA BRYTYJSKICH DELEGATÓW NA KONFERENCJĘ POKOJOWĄ W PARYŻU W 1919 ROKU
}

\author{
Paweł Hanczewski \\ http://orcid.org/0000-0003-4164-6310 \\ Uniwersytet Mikołaja Kopernika w Toruniu
}

\section{ABSTRACT \\ COURSES IN POLISH HISTORY FOR THE BRITISH DELEGATES AT THE PARIS PEACE CONFERENCE IN 1919}

In the spring of 1917 the Admiralty established a historical section whose main duty was to provide the British delegates to the Peace Conference with geographical, economic, historical, social, religious and political information regarding different parts of the world. The section prepared 174 handbooks which, due to a great interest from the British public, were issued for general and public use in 1920. One of the subjects discussed in the handbooks was the history of Poland from 1569 to the outbreak of the First World War. This subject was of great significance as the authors of the handbooks adopted historical reasoning, i.e. they believed that the origins of present-day problems and their solutions could be found through studying history. The aim of the article is to assess the knowledge of Poland's history as presented in the handbooks and to learn to what extent this knowledge influenced British policy towards Poland during the Peace Conference.

Key words: History of Poland, Great Britain, the Paris Peace Conference.

Słowa kluczowe: historia Polski, Wielka Brytania, konferencja pokojowa w Paryżu.

Wiosną 1917 roku w brytyjskim Ministerstwie Admiralicji i Spraw Morskich (Admiralicja) utworzono specjalną sekcję historyczną, której zadaniem było przygotowanie materiałów informacyjnych dla brytyjskich delegatów na konferencję pokojową ${ }^{1}$ W pierwszych miesiącach następnego roku sekcja została włączona w skład Ministerstwa Spraw Zagranicznych (Foreign Office). Utworzenie sekcji stanowiło część brytyjskich przygotowań do konferencji pokojowej rozpoczętych w sierpniu

1 E. Goldstein, Winning the Peace. British Diplomatic Strategy, Peace Planning, and the Paris Peace Conference, 1916-1920, Oxford 1991, s. 30-31.

Adres do korespondencji: ph@umk.pl 
1916 roku, w których uczestniczyły także Biuro Premiera, Ministerstwo Wojny i Ministerstwo Skarbu². Efektem prac sekcji historycznej były 174 zeszyty (handbooks), poświęcone zagadnieniom ,geograficznym, gospodarczym, historycznym, społecznym, religijnym i politycznym" związanym z ustaleniem ładu powojennego. Szefem sekcji i osobą odpowiedzialną za całość wydawnictwa był jeden z najwybitniejszych ówczesnych historyków, George Walter Prothero. O ile wiemy, kto sprawował ogólny nadzór nad edycją zeszytów, o tyle niestety nie znamy autorów poszczególnych części. W notce redakcyjnej stwierdzono jedynie, że zeszyty zostały opracowane przez „autorów mających przygotowanie do pisania o historii”, zachowując ich anonimowość ${ }^{3}$.

Większość zeszytów została wyodrębniona na podstawie kryterium geograficznego. Obejmowały one cały świat, z wyjątkiem Australii i Antarktydy, przy czym najwięcej uwagi poświęcono sprawom Europy - 56 zeszytów. Szczególnie dużo miejsca zajął obszar rozciągający się od Niemiec do Rosji i od Finlandii do Grecji, z którym wiązało się najwięcej problemów - łącznie 42 zeszyty. Wśród nich znalazły się zeszyty poświęcone Polsce i Polakom. Część zeszytów wyodrębniono, wykorzystując kryterium rzeczowe. W tej kategorii znalazły się między innymi zeszyty: Kongresy $i$ konferencje międzynarodowe, Koncepcje utrzymania pokoju, Polityka prezydenta Wilsona. Różnice między nimi mogły być duże. Jeśli w ostatnim zeszycie ograniczono się do przedrukowania wystąpień publicznych prezydenta Wilsona między początkiem sierpnia 1914 roku a początkiem grudnia 1918 roku, to w zeszycie Koncepcje utrzymania pokoju dokonano analizy tytułowego zagadnienia ${ }^{4}$. Wydawnictwo uzupełniały cztery zeszyty z mapami: Mapy Austro-Węgier, Mapy Półwyspu Batkańskiego, Mapy Polski, Mapy etnograficzne Europy Centralnej i Południowej oraz Zachodniej Azji

Pierwotnie zeszyty były przeznaczone dla delegatów na konferencję pokojową, ale ze względu na duże zainteresowanie opinii publicznej w 1920 roku wydano je w ogólnodostępnej formie, kierując je do „badaczy historii, polityki, gospodarki i spraw zagranicznych, dziennikarzy, biznesmenów i podróżników". Najbardziej widoczna zmiana w stosunku do materiałów, które otrzymali delegaci, polegała na tym, że zmniejszono liczbę zeszytów ze 170 do 165 . Inna zmiana polegała na tym, że pojawiła się nowa numeracja niektórych zeszytów. Wynikało to z wprowadzenia w tej wersji podziału na części oznaczane literami od (A) „Europa” do (F) „Mapy”, a w ramach części podziału na tomy, na przykład tom $\mathrm{V}$ „Niderlandy” złożony z pięciu zeszytów. Zmiany wynikały z dążenia do uporządkowania zeszytów, aby ułatwić ich lekturę. Nie oznaczały natomiast zmian ani układu, ani treści. Mimo że przed

2 Ibidem, s. 9, 19-56, 281.

3 Zob. Editorial note w: Austria. Hungary. Foreign Policy of Austria-Hungary, nr 1, [b.p.].

4 International Congresses and Conferences, nr 151; Schemes for Maintaining General Peace, nr 160; President Wilson's Policy, nr 161.

5 Maps of Austria-Hungary; Maps of the Balkan Peninsula; Maps of Poland; Ethnographical Maps of Central and South-Eastern Europe and Western Asia, wszystkie mapy bez numerów zeszytów (dalej: [b.n.zesz.]).

${ }^{6}$ Editorial Note [w:] Austria. Hungary..., [b.p.]). 
drukiem wersji ogólnodostępnej Rosja pogrążyła się w chaosie rewolucji, podpisano traktat pokojowy z Niemcami, w Europie rozpadły się stare imperia, a na ich miejsce powstały nowe państwa, nie uwzględniono tych wydarzeń, tłumacząc to nadal niestabilną sytuacją oraz kosztami wprowadzenia zmian.

Układ treści w większości zeszytów był bardzo podobny. Pierwszy rozdział nosił tytuł „Geografia fizyczna i polityczna”. Przedstawiano w nim położenie i granice danego obszaru, ukształtowanie terenu i system rzeczny, klimat, wreszcie zagadnienia ludnościowe. Znajdowały się tu dane statystyczne na temat wielkości populacji, poszczególnych grup narodowych oraz ich rozmieszczenia, ludności miejskiej i wiejskiej, przyrostu naturalnego dla całej populacji, jak i poszczególnych grup narodowych, wskaźników śmiertelności, wreszcie ruchów ludności, przede wszystkim ze wsi do miasta, oraz emigracji. Drugi rozdział był poświęcony historii politycznej regionu. Zaczynał się od przedstawienia w porządku chronologicznym najważniejszych wydarzeń, po czym omawiano dzieje obszaru, kierując się zasadą, że im bliżej czasów współczesnych, tym więcej informacji. Trzeci rozdział nosił tytuł „Warunki społeczne i polityczne". Omawiano w nim takie kwestie, jak sytuację poszczególnych narodów, ich wpływ na życie polityczne i gospodarcze, stosunki wyznaniowe oraz poziom edukacji. Rozdział czwarty był poświęcony zagadnieniom ekonomicznym, choć w kilku zeszytach ta część się nie pojawiła. Dotyczyło to obszarów, które uznano za pozbawione znaczenia gospodarczego. Z perspektywy naszych czasów najbardziej zaskakuje brak takiej części w zeszycie Zatoka Perska ${ }^{7}$. Informacje były bardzo szczegółowe i dotyczyły takich kwestii, jak sieć transportowa, produkcja rolna i przemysłowa, handel zagraniczny, bankowość, rynek pracy i warunki pracy. W większości zeszytów była to najdłuższa część, niekiedy kończyły ją uwagi ogólne. W niektórych zeszytach pojawiała się część zatytułowana „Dodatki”, która zawierała różnego rodzaju dokumenty. Na końcu umieszczano listę prac wykorzystanych przy opracowaniu zeszytu, pozostawiając autorom wolną rękę w ich doborze.

W tym artykule chciałbym skoncentrować się na tym, w jaki sposób w zeszytach przedstawiono historię Polski. Jest to istotne zagadnienie nie tylko ze względu na możliwość poznania i oceny poziomu wiedzy dotyczącej przeszłości Polski zawartej w zeszytach, ale przede wszystkim ze względu na fakt, że powstały one w wyjątkowo ważnym okresie dla sprawy polskiej. Mimo iż we „Wstępie” zaznaczono, że zeszyty nie zostały przygotowane przez Foreign Office oraz że ministerstwo nie gwarantuje dokładności wszystkich informacji ani nie akceptuje wszystkich opinii, to równocześnie podkreślono, że materiały zostały przygotowane na potrzeby Foreign Office i delegatów na konferencję pokojową. Miały więc przynajmniej częściowo oficjalny charakter i pierwotnie były adresowane do osób, które miały znaczący wpływ na kształtowanie ładu powojennego. Zeszyty dostarczały nie tylko wiedzy, ale też interpretacji. Ich autorzy często wyrażali swój stosunek do poruszanych zagadnień. Czynili to albo w osobnych częściach zatytułowanych „Uwagi ogólne”, albo poprzez krótkie oceny, bez nadawania im formy osobnych punktów. Kolejnym sposobem było przedstawienie określonego zagadnienia tylko z jednego punktu widzenia

7 Persian Gulf, nr 76. 
i świadomego pomijania innych perspektyw. W zeszytach dominowało myślenie historyczne polegające na tym, że w przeszłości szukano źródeł obecnej sytuacji oraz sposobów rozwiązania istniejących problemów. Bez części historycznej zeszyty byłyby tylko zbiorem informacji i danych liczbowych. Wykład historyczny miał odpowiedzieć na podstawowe pytanie, przed którym stanęli delegaci na konferencję pokojową: co należy zrobić, aby ustanowić trwały pokój? Miało to decydujący wpływ na sposób przedstawiania dziejów, ponieważ koncentrowano się na tych zagadnieniach, które - jak uważano - przyczyniły się do wybuchu wojny i stały na przeszkodzie do zapewnienia pokoju. Wszystkie inne elementy, na przykład współpracę między państwami czy dobre relacje między narodami, pomijano, co mogło wywoływać u odbiorców wrażenie, że dzieje poszczególnych państw czy narodów stanowiły pasmo konfliktów wewnętrznych i zewnętrznych, którym należy wreszcie położyć koniec, aby nie powtórzył się koszmar „wielkiej wojny”.

Na potrzeby delegatów przygotowano dwa zeszyty poświęcone historii Polski, Polska: Historia 1571-1774 oraz Polska: 1774-1815, które w wydaniu ogólnodostępnym połączono w zeszyt Polska: Ogólny zarys historii 1569-18158. Informacje na temat dziejów Polski nie ograniczały się do jednego zeszytu. Umieszczono je również w materiałach dotyczących tych obszarów, które odpadły od państwa polskiego w czasie jego istnienia (np. w zeszycie Austriacki Śląsk zwrócono uwagę, że w XI i XII wieku Śląsk był obiektem rywalizacji między Polską, Czechami i cesarstwem ${ }^{9}$ ), oraz tych terenów, które w wyniku rozbiorów znalazły się pod obcym panowaniem. Łącznie wiadomości znalazły się w 11 zeszytach opartych na kryterium geograficznym ${ }^{10}$. Do tego należy doliczyć trzy zeszyty wyodrębnione z wykorzystaniem kryterium rzeczowego oraz takiej samej liczby zeszytów z mapami ${ }^{11}$.

Głównym źródłem wiedzy na temat dziejów Polski przedrozbiorowej był wspomniany zeszyt Polska: Ogólny zarys historii 1569-1815. Jest stosunkowo krótki, liczy 29 stron tekstu, ale nie świadczy to o lekceważeniu tematu. Bardziej uzasadniona byłaby teza przeciwna, ponieważ dla całego kontynentu europejskiego opracowano tylko dwa podobne zeszyty, Historia Austrii oraz Historia Wegier ${ }^{12}$. Przygotowując zeszyt, skorzystano z ośmiu prac, które wymieniono na końcu. Obok przypadkowych pozycji, takich jak wydana w 1864 roku Historie de la Revolution

8 Poland: History 1571-1774; Poland: 1774-1815; Poland: General Sketch of History 1569-1815, nr 43.

9 Austrian Silesia, $\mathrm{nr}$ 4, s. 9-10.

10 Austrian Silesia, nr 4; Bukovina, nr 5; Hungarian Ruthenia, nr 7; East and West Prussia, nr 39; Upper Silesia, nr 40; Poland: General Sketch of History 1569-1815, nr 43; Russian Poland, Lithuania and White Russia, nr 44; Prussian Poland, nr 45; Austrian Poland, $\mathrm{nr}$ 46; Courland, Livonia and Esthonia, nr 50; The Ukraine, $\mathrm{nr} 52$.

11 International Rivers, $\mathrm{nr}$ 149; The Congress of Vienna, nr 153; President Wilson's Policy, nr 161; Maps of Austria-Hungary, [b.n.zesz.]; Maps of Poland, [b.n.zesz.]; Ethnographical Maps of Central and South-Eastern Europe and Western Asia, [b.n.zesz.].

12 W wersji dla delegatów ukazały się odrębne zeszyty History of Austria oraz History of Hungary. W wydaniu ogólnodostępnym połączono je z zeszytem Foreign Policy of Austria-Hungary, co dało łącznie wspomniany już zeszyt Austria. Hungary. Foreign Policy of Austria-Hungary, nr 1. 
Polonaise (1772 a 1864) oraz The Partition of Poland ${ }^{13}$, znajdziemy fachową literaturę. Dotyczy to szczególnie tomów The Political History of Poland oraz Poland's Case for Independence wydanych z inicjatywy Komitetu Narodowego Polskiego ${ }^{14}$. Zabrakło natomiast, z wyjątkiem francuskich wydań Historii Polski Joachima Lelewela oraz Sprawy polskiej Tomasza Starczewskiego ${ }^{15}$, innych prac badaczy polskich czy pozycji w języku polskim ${ }^{16}$.

Przyjęcie roku 1569 jako daty początkowej związane jest z unią lubelską, ale w szerszej perspektywie wskazuje na podstawowy cel zeszytu. Było nim wyjaśnienie przyczyn rozbiorów i likwidacji państwa polskiego, a właśnie związek Polski z Litwą i jego konsekwencje uznano za jedną z najważniejszych przyczyn. Mimo rozpoczęcia narracji w roku 1569 wydarzeniem, z którego perspektywy opisywano historię Polski, był I rozbiór, prowadzący ostatecznie do upadku państwa. Z takim podejściem wiąże się ryzyko polegające na skupieniu uwagi tylko na tych elementach, które przyczyniły się do likwidacji państwa, a w rezultacie na wyrobieniu wśród czytelników wrażenia, że był to proces nieuchronny. W czasie kiedy przygotowano zeszyty, sprzyjała temu dominacja w historiografii brytyjskiej „wigowskiej interpretacji dziejów", która posługiwała się determinizmem historycznym. W tym wypadku chodziło o przedstawienie dziejów Anglii, a następnie Wielkiej Brytanii jako niepowstrzymanego rozwoju systemu politycznego i społecznego w kierunku monarchii konstytucyjnej i demokracji, co znalazło finał w XIX-wiecznym państwie liberalnym. Mimo że taka interpretacja odnosiła się do dziejów Wysp Brytyjskich, to do lat 30. XX wieku i publikacji książki Herberta Butterfielda ${ }^{17}$ miała wyraźny wpływ na większość historyków bez względu na przedmiot ich badań.

Zeszyt, pomijając krótką tablicę chronologiczną i równie krótkie opisanie granic państwa polsko-litewskiego w XVI wieku, podzielono na cztery okresy. Pierwszy, obejmujący lata 1569-1632, zatytułowano „Reakcja katolicka”. Drugi, lata 16321688, „Wojny kozackie”, trzeci zaś okres, obejmujący lata 1669-1772, nosił tytuł „Dominacja Rosji do pierwszego rozbioru”. W każdym z tych okresów wprowadzono też dwa podrozdziały, jeden omawiający sytuację wewnętrzną, drugi - zewnętrzną. W czwartym okresie, obejmującym lata 1772-1815, „Rozbiory i porozumienie 1815 roku”, wyodrębniono osiem części, kolejno: „Pierwszy rozbiór 1772”, „Reformy wewnętrzne”, „Drugi rozbiór 1793”; „Polskie powstanie”, „Trzeci rozbiór 1795”, „Wydarzenia między rokiem 1795 a 1807”, „Księstwo Warszawskie” i wreszcie „Kongres wiedeński 1814-1815”.

13 S. Araminski, Historie de la Revolution Polonaise (1772 a 1864), Paris 1864. Autorem tego dzieła był Jan Artemi Fayard. G. Shaw-Lefevre, The Partitions of Poland, London 1915.

14 E.H. Lewiński-Korwin, The Political History of Poland, New York 1917; Poland's Case for Independence, London 1916.

15 J. Lel ew el, Historie de Pologne, 2 Vols., Paris 1844; T. Starczew ski, L'Europe et la Pologne, Paris 1913.

16 Nie wspomniano również o wartościowych opracowaniach w języku angielskim, dotyczy to szczególnie kolejnych tomów The Cambridge Modern History. O Polsce w tomach V i VIII pisał Richard Lodge, natomiast Szymon Askenazy był autorem dwóch rozdziałów w tomie X.

17 H. Butterfield, The Whig Interpretation of History, London 1931. 
Nazwy poszczególnych okresów są jednak mylące, ponieważ w każdym przypadku omawiano cały szereg problemów, nie ograniczając się do tytułowego zagadnienia. Pierwszy okres otwierają uwagi na temat systemu politycznego Rzeczpospolitej, którego najważniejszą cechą była ciągła rywalizacja między szlachtą a kolejnymi władcami. Jej skutkiem był system, który określono jako „nieskuteczny”18 głównie ze względu na słabość władzy królewskiej, której wzmocnienie uniemożliwiał, obok postawy szlachty, brak ciągłości politycznej wynikający z systemu monarchii elekcyjnej. Przy tej okazji poruszono tytułowe zagadnienie „reakcji katolickiej”. Mimo że w Wielkiej Brytanii termin budził najczęściej negatywne skojarzenia ${ }^{19}$, to w wypadku Polski zwrócono uwagę także na konsekwencje pozytywne. Wadą było ograniczenie tolerancji religijnej i pogorszenie relacji między wyznawcami różnych odłamów chrześcijaństwa. Równocześnie jednak „reakcja katolicka”, a szczególnie współpraca kolejnych władców z jezuitami, stanowiła przeciwwagę dla tendencji odśrodkowych związanych z reformacją oraz „buntowniczą naturą” szlachty, przyczyniając się do zachowania całości i suwerenności państwa w XVII wieku. Kolejne ważne elementy, które omówiono, to unia lubelska oraz sytuacja społeczna związana $\mathrm{z}$ położeniem miast i chłopów. W przypadku miast pisano o kryzysie wynikającym z polityki szlachty oraz zdominowania życia miejskiego przez obcokrajowców, przede wszystkim Żydów. W przypadku chłopów podkreślono, że mimo zależności od szlachty ich sytuacja była na tyle dobra, że w wieku XVI i XVII „chłopi migrowali do Polski ze wszystkich części Europy"20. W dziedzinie polityki zagranicznej położenie Polski oceniono jako ogólnie dobre, zwracając uwagę na wielkie sukcesy militarne, których jednak nie umiano wykorzystać ze względu na sytuację wewnętrzną oraz na nadmierne rozproszenie sił wynikające $\mathrm{z}$ wojen prowadzonych na odległych od siebie obszarach. W drugim okresie kontynuowano wątek rywalizacji między szlachtą a władcami, przy czym zwrócono uwagę na nowy element, jakim było pojawienie się grupy magnatów, która nie tylko zdominowała ogół szlachty, ale i doprowadziła do faktycznego podziału państwa na „,szereg niezależnych jednostek administracyjnych". Sytuacja była tak zła, że Jan Kazimierz został zmuszony do abdykacji, kiedy Polska najbardziej potrzebowała jedności ${ }^{21}$. Jeszcze większym zagrożeniem dla Rzeczpospolitej okazały się wojny domowe i zewnętrzne, które doprowadziły do pierwszego podziału terytorium między sąsiadów. Mimo że Polska zdołała się obronić, to wyszła z wojen bardzo osłabiona, a od traktatu andruszowskiego Rosja stopniowo ją sobie podporządkowała. W trzecim okresie Polska pogrążyła się w anarchii, której symbolami miały być liberum veto oraz brak tolerancji religijnej, podsycane i wykorzystywane przez Rosję. Sytuację dodatkowo pogarszali nieudolni władcy. August II miał zaproponować podział Polski między Prusy i Rosję, jego syna określono jako „Zwykłe zero”22. Za rządów tego drugiego rozpoczęła

18 Poland: General Sketch..., s. 5.

19 I. Sakowicz-Tebinka, Imperium barbarzyńców. Rosja Aleksandra II w brytyjskich opiniach prasowych, Gdańsk 2010, s. 179.

20 Poland: General Sketch..., s. 3.

21 Ibidem, s. 8-9.

22 Ibidem, s. 14. 
się rywalizacja między Potockimi a Familią, ale jej skutki były niekorzystne dla państwa, ponieważ została wykorzystana przez Rosję do utrzymania anarchii w Polsce. Rosja w trakcie wielkiej wojny północnej zyskała decydujący wpływ na jej sprawy, a co gorsza - ambicje terytorialne jej kosztem otwarcie przejawiały też Prusy.

Podsumowanie okresu 1569-1772 znalazło się w części zatytułowanej „Przyczyny upadku". W pierwszej kolejności wymieniono działania Rosji, która uniemożliwiła Polsce „uporządkowanie własnych spraw”. Na drugim miejscu znalazła się agresywna i „cyniczna” polityka Fryderyka II. Na trzecim umieszczono cały szereg problemów wynikających z rozmiaru terytorium Rzeczpospolitej. Obok niekorzystnego położenia strategicznego między agresywnymi sąsiadami i brakiem naturalnych granic obronnych polska polityka zagraniczna była rozdarta między dwoma obszarami. Za „właściwą strefę” dla ekspansji Polski uznano Śląsk, Pomorze i część Prus położoną nad Morzem Bałtyckim. $Z$ tego punktu widzenia jako największy błąd przedstawiono unię lubelską. Mimo że na pewien czas powstrzymała ekspansję Rosji, to w dłuższej perspektywie doprowadziła do nadmiernego rozproszenia sił na arenie międzynarodowej. Kolejnym negatywnym skutkiem unii było wyjście przez Polskę poza granice etnograficzne. Nie zdołano ani spolonizować mieszkańców Ukrainy, ani zasiedlić jej wystarczającą liczbą Polaków. Zdołano natomiast wywołać konflikt religijny, który Rosja wykorzystała do oderwania części terytorium, a ostatecznie do podporządkowania sobie Polski. Próby kolonizacji Ukrainy osłabiły też potencjał ludnościowy Polski, co miało „katastrofalny wpływ na dzieje polityczne i gospodarcze całego państwa"23. Inną negatywną konsekwencją unii lubelskiej było powstrzymanie centralizacji państwa, i to w czasie, gdy sąsiednie mocarstwa rozpoczęły proces rozbudowy armii i wzmacniania władzy centralnej. Na kolejnym miejscu wśród przyczyn upadku państwa wymieniono „źle zrównoważoną strukturę społeczeństwa". Pod tym pojęciem kryła się duża ilość szlachty, która była zainteresowana głównie obroną własnych interesów. Szczególnie negatywną rolę odegrali magnaci kontrolujący większość średniej i ubogiej szlachty, zabiegając przy tym o poparcie obcych dworów. „Źle zrównoważona struktura społeczna” oznaczała też brak stanu trzeciego. Wynikał on z napływu od XVI wieku Żydów korzystających $\mathrm{z}$ niespotykanych w żadnym innym miejscu Europy przywilejów. Zdominowali oni życie miast, uniemożliwiając powstanie polskiego stanu trzeciego, który mógłby zachować równowagę między władcą a szlachtą. Ostatnią przyczyną upadku państwa był rozdźwięk między ideologią szlachty a praktyką życia politycznego. Z jednej strony o ideologii wyrażano się z uznaniem: „wyprzedzająca czasy i często stojąca w opozycji do całej współczesnej teorii i praktyki życia politycznego"24. Równocześnie podkreślano, że ideały republikańskie pozostawały w sferze teorii, w praktyce Polska była „niespokojną oligarchią"25.

Stopniową likwidację państwa polskiego po roku 1772 przedstawiono w ostatnim, czwartym okresie obejmującym lata 1772-1815. Proces ten opisano wyłącznie

\footnotetext{
23 Ibidem, s. 18.

24 Ibidem, s. 19.

25 Ibidem.
} 
jako efekt działania obcych mocarstw, z którymi była gotowa współpracować nieliczna grupa magnatów. Po przeciwnej stronie znalazła się większość społeczeństwa, w tym warstwy wykształcone, Kościół rzymskokatolicki i szlachta, która podjęła wysiłek reformatorski. Rezultatem był rozwój gospodarczy, społeczny i kulturalny kraju. W dziedzinie polityki najważniejszym osiągnięciem była Konstytucja 3 maja. Jednak polityka Rosji i Prus, które czekały na okazję do kolejnego podziału ziem polskich, przekreśliły wysiłki Polaków, prowadząc najpierw do drugiego rozbioru a następnie, po powstaniu kościuszkowskim, do likwidacji państwa polskiego. Rozbiory doprowadziły do wzrostu uczuć patriotycznych na niespotykaną wcześniej skalę. Patriotyzm stał się elementem wspólnym dla Polaków żyjących pod trzema zaborami, znajdując wyraz między innymi w działaniach zmierzających do odbudowy państwa. Po roku 1795 los Polski był uzależniony od wielkich mocarstw, które po klęsce Napoleona dokonały jej kolejnego rozbioru, bez zwracania uwagi na pragnienia Polaków.

Powyższa interpretacja, szczególnie dotycząca okresu 1569-1772, umyka prostym ocenom. Podjęto próbę obiektywizacji, polegającą na odrzuceniu determinizmu historycznego, zgodnie z którym upadek państwa polskiego był zdarzeniem nieuchronnym ze względu na „polską anarchię”. Zaproponowano spojrzenie, które uwzględnia czynniki wewnętrzne i zewnętrzne, polityczne, religijne, społeczne i narodowościowe, wskazując przy tym na elementy negatywne i pozytywne. Wprowadzono też podział na długo- i krótkotrwałe przyczyny upadku. Wśród pierwszych wymieniono między innymi system polityczny i społeczny oraz unię lubelską i jej następstwa polityczne. Nie oznaczało to akceptacji poglądu, że od drugiej połowy XVI wieku Polska była skazana na upadek, tym bardziej że - jak zaznaczono - inicjowano próby reform. Do likwidacji państwa konieczne były działania krótkoterminowe podejmowane przez konkretnych polityków w konkretnym czasie - tutaj na szczególnie złą ocenę zasłużyli Katarzyna II i Fryderyk II $^{26}$. W takim ujęciu rozbiory Polski wynikały z połączenia szeregu elementów pojawiających się w różnych okresach. Dla autora zeszytu punktem wyjścia nie było zatem pytanie, dlaczego państwo polskie musiało upaść, ale dlaczego, mając możliwości rozwoju, upadło. Równocześnie jednak w zeszycie pojawiły się opinie, że w gruncie rzeczy Polska, ze względu na anarchię, która była wytworem sił wewnętrznych, wykorzystaną następnie przez obce państwa, zasłużyła na pierwszy rozbiór, choć nie na następne: „Pierwszy rozbiór Polski był do pewnego stopnia uzasadniony istniejącą w niej anarchią, drugi był bezczelnym rozbojem dokonanym na bezsilnym sąsiedzie" ${ }^{27}$.

Mimo tej opinii ocena dziejów Polski wypada pozytywnie, przede wszystkim z tego względu, że zwrócono uwagę na niesprawiedliwość polegającą na likwidacji państwa polskiego oraz na gotowość Polaków najpierw do głębokich zmian politycznych i społecznych, a następnie do walki o niepodległość ojczyzny. Zeszyt przygotowano dla brytyjskich delegatów, którzy traktowali jako „normalną” sytuację, kiedy nie było państwa polskiego. W zeszycie popierano, opierając się na materiale

\footnotetext{
26 Ibidem, s. 15-17, 21-23.

27 Ibidem, s. 24.
} 
historycznym, ideę odbudowy suwerennego państwa polskiego, nie „Polski” wchodzącej w skład któregoś z mocarstw środkowo- bądź wschodnioeuropejskich. Służyło temu między innymi podkreślanie długotrwałej rywalizacji między Polską a Rosją, a także wrogiego stosunku Prus do Polski.

Wątpliwości zaczynają się przy ocenach dotyczących przyszłości Polski. Zgodnie z zasadą historia magistra vitae - w zeszycie pojawił się dosłowny zarzut, że „,naród jako całość nie był w stanie nauczyć się niczego z wcześniejszych niepowodzeń”28, autor uznał, że na podstawie analizy materiału historycznego możliwe jest określenie, jaki kształt terytorialny i polityczny powinna mieć niepodległa Polska, aby zapewnić jej bezpieczeństwo i trwały rozwój. Przeniesienie ocen z wieków przeszłych do początku XX stulecia było zdaniem autora o tyle uzasadnione, że mimo upływu czasu pewne elementy pozostały niezmienione. Jednym z nich było niekorzystne położenie strategiczne Polski między potężnymi i agresywnymi sąsiadami. Innym - wielonarodowy charakter obszarów, na których odbudowywano państwo polskie. Odrodzone państwo polskie powinno unikać polityki na dwa fronty, koncentrując uwagę na kierunku zachodnim i północnym. Konsekwencją byłaby rezygnacja z ziem znajdujących się poza ,polskim obszarem etnicznym”, przez co rozumiano tereny zamieszkane w większości przez Litwinów i Ukraińców. Takie działanie pozwoliłoby uniknąc konfliktów ze wschodnim sąsiadem bądź sąsiadami, polepszając sytuację geopolityczną. Pozwoliłoby również uniknąc konfliktów wewnętrznych związanych z wielonarodowym charakterem państwa, który przedstawiano jako jedną z głównych przyczyn jego wewnętrznej słabości i upadku. Wreszcie - odrodzona Polska powinna mieć sprawny rząd centralny oraz nowoczesną strukturę społeczną, bez dominacji jednej tylko grupy.

Kto był autorem tych poglądów? Głównymi specjalistami w sprawach polskich współpracującymi z Foreign Office byli profesor uniwersytetu w Oksfordzie, Charles William Chadwick Oman oraz Lewis Namier. O stosunku tego ostatniego do odradzającego się państwa polskiego wielokrotnie już pisano ${ }^{29}$. Na rzecz Omana przemawiają dwa elementy. Pierwszy to wykorzystana literatura, która w kilku wypadkach budzi wątpliwości i nie uwzględnia ani jednej pozycji w języku polskim. Uzasadnione wydaje się przypuszczenie, że Namier, który był wychowany w kręgu kultury polskiej i który świetnie znał prace historyków polskich, skorzystałby z ich dorobku ${ }^{30}$.

28 Ibidem, s. 13.

29 A. Cienciała, Polityka brytyjska wobec odrodzenia Polski, 1914-1918, ,Zeszyty Historyczne” 1969, z. 16, s. 76-79; J. Namier, Lewis Namier: A Biography, London 1971, s. 122-123, 127; M. Nowak-Kiełbikowa, Polska-Wielka Brytania w latach 1918-1923. Kształtowanie się stosunków politycznych, Warszawa 1975, s. 60, 197-198; T. P is zc zkow ski, Anglia a Polska 1914-1939 wświetle dokumentów brytyjskich, Londyn 1975, s. 3, 24-25, 49-52, 54, 62, 69, 78, 83-84, 87; B. Ru sin, Lewis Namier a kwestia , linii Curzona” i ksztattowania się polskiej granicy wschodniej po I wojnie światowej, „Studia z Dziejów Rosji i Europy Środkowo-Wschodniej” 2013, t. 48, s. 95-115; A. Zi ęba, Historyk jako produkt historii, czyli o tym, jak Ludwik Bernstein przekształcat się w Lewisa Namiera [w:] Historyk i Historia. Studia dedykowane pamięci Prof. Mirosława Frančicia, red. A. Walaszek, K. Zamorski, Kraków 2005, s. 149-174; A. Nowak, Pierwsza zdrada Zachodu. 1920 - zapomniany appeasement, Kraków 2015, s. 235-265.

30 A. Zięba, op. cit., s. 162, 173. 
W wielu zeszytach wymieniano opracowania i materiały źródłowe w innych językach niż angielski. Drugi element to bardzo krytyczna ocena roli Żydów, nie tylko w dziedzinie gospodarczej, ale i społecznej. To właśnie ich obecność zdaniem autora zeszytu miała uniemożliwić pojawienie się polskiego „stanu trzeciego”, przyczyniając się pośrednio do upadku państwa.

Dzieje Polski po roku 1815, przez co rozumiano dzieje narodu polskiego między zakończeniem prac kongresu wiedeńskiego a początkiem wojny światowej, przedstawiono w rozdziałach historycznych kilku zeszytów. Najwięcej miejsca poświęcono im w zeszytach Rosyjska Polska. Litwa i Biatoruś, Pruska Polska, Austriacka Polska, Prusy Wschodnie i Zachodnie oraz Górny Ślask. Przez „pruską Polskę” rozumiano Wielkie Księstwo Poznańskie, a po 1848 roku rejencje poznańską i bydgoską, przez „rosyjską Polskę” Królestwo Polskie utworzone decyzją kongresu wiedeńskiego, przez „austriacką Polskę” Galicję, nie wliczając w jej skład Bukowiny. Górny Śląsk pokrywał się z obszarem rejencji opolskiej. Fakt, że w tytułach niektórych zeszytów nazwa „Polska” pojawia się dla określenia terytorium wchodzącego w skład państw obcych, nie był oznaką antypolonizmu. Przygotowując zeszyty dla delegatów, kierowano się istniejącymi podziałami politycznymi, a to, że w wersji ogólnodostępnej nie wprowadzono zmian, wynikało z założeń przyjętych dla całego wydawnictwa.

Autorzy wspomnianych zeszytów skoncentrowali uwagę na procesie tworzenia nowoczesnego narodu polskiego oraz polityce władz zaborczych wobec Polaków. Mimo różnej przynależności państwowej Polaków uznano za członków tego samego narodu. W przeciwieństwie do ziem byłego państwa polskiego nie podzielono ich na „austriackich Polaków”, „pruskich Polaków” czy „rosyjskich Polaków”. Wynikało to nie tylko z podkreślanego przez autorów zeszytów poczucia wspólnoty historycznej i kulturowej między Polakami, ale także z podobnych wyzwań, przed którymi stanęli, oraz ze zmian społecznych, które do wojny światowej pozwoliły na powstanie nowoczesnego narodu polskiego.

Na początku XIX wieku sytuacja narodowa na wszystkich obszarach wyglądała bardzo podobnie. Naród polski ograniczał się do szlachty, która zachowała uprzywilejowany status wobec pozostałych grup. Taką ocenę najlepiej oddaje zdanie przedstawiające sytuację w „pruskiej Polsce”, które można odnieść do pozostałych ziem polskich: „W 1815 roku Polacy składali się z niewykształconych chłopów, którzy pod wszystkimi względami byli zdominowani przez posiadającą ziemię szlachtę" "31. Wyjątkowo tylko świadomość narodową posiadała część „burżuazji warszawskiej”, co znalazło wyraz w jej udziale w powstaniu listopadowym ${ }^{32}$. Świadomość narodowa szlachty nawiązywała jednak do nieistniejącego już świata Polski przedrozbiorowej. Ograniczona wyłącznie do jednej warstwy, odrzucająca myśl o reformach społecznych i gospodarczych, dostrzegała możliwość odzyskania niepodległości w powstaniach i wsparciu z zewnątrz. Taką świadomość określono jako „romantyczny nacjonalizm”33, całkowicie nieprzystający do nowych czasów i sprowadzający

\footnotetext{
1 Prussian..., s. 12.

32 Russian..., s. 30.

33 Prussian..., s. 20.
} 
na Polaków klęski w powstaniach ${ }^{34}$. Jednak w ciągu XIX wieku polska świadomość narodowa, a w konsekwencji rozumienie pojęcia narodu polskiego, uległy zmianie, co w dużym stopniu było niezamierzonym skutkiem polityki rządów państw zaborczych.

W roku 1815 żadne z tych państw nie miało długofalowego planu działań wobec polskich poddanych. W „rosyjskiej Polsce” pierwsze lata wyglądały obiecująco. Królestwo Kongresowe otrzymało konstytucję, którą określono jako ,jedną z najbardziej liberalnych w Europie”, cieszyło się też „daleko posuniętą niezależnością”. Jak jednak podkreślano, było to raczej wynikiem kaprysu cara Aleksandra I niż zrozumienia dążeń Polaków ${ }^{35}$. Od 1819 roku konstytucja była nagminnie łamana, co doprowadziło do wybuchu powstania listopadowego ${ }^{36}$. Jego ocena, podobnie jak wszystkich pozostałych zrywów zbrojnych, była negatywna ze względu na brak możliwości zwycięstwa militarnego, nieudolne przywództwo oraz postawę szlachty, która chciała zachować istniejącą strukturę społeczną. Powstanie rozpoczęło nowy okres w polityce caratu wobec „rosyjskiej Polski”, który trwał do początku wojny światowej. Za główne cele tej polityki autor zeszytu uznał likwidację odrębności prawno-ustrojowych między Królestwem a cesarstwem oraz - po powstaniu styczniowym - rusyfikację Polaków. Władze próbowały je zrealizować przede wszystkim poprzez osłabienie szlachty jako najbardziej świadomej narodowo części społeczeństwa oraz wykorzystanie szkolnictwa do rusyfikacji pozostałych warstw. W zeszycie wymieniono między innymi zmiany prawne, zsyłki na Syberię, konfiskatę majątków w ramach represji popowstaniowych, napływ dużej liczby urzędników rosyjskich i rusyfikację instytucji. Zwrócono uwagę na okresy względnego złagodzenia polityki wobec Królestwa, podkreślając jednak, że trwały krótko i wynikały z problemów Rosji. Nawet rewolucja 1905 roku przyniosła bardzo ograniczone i tymczasowe ustępstwa. Postawa władz i dużej części rosyjskiej opinii publicznej wobec Polaków była wroga $^{37}$. Działania rządzących spotkały się z potępieniem ze strony autora zeszytu. Próby rusyfikacji, ze względu na wyższość kulturową Polaków, były od początku skazane na niepowodzenie, przyczyniając się tylko do rozwoju polskiej świadomości narodowej i wrogości wobec Rosji ${ }^{38}$. Łącznie politykę caratu wobec Królestwa w latach 1815-1914 widziano jako „dzieje reakcji i represji” ${ }^{39}$.

Równie negatywna była ocena polityki pruskiej. Podobnie jak w Królestwie do roku 1830 próbowano osiągnąc porozumienie z polską warstwą przywódczą, gwarantując jej dominację w lokalnym życiu politycznym. Poparcie szlachty dla powstania listopadowego skłoniło władze pruskie do rewizji tej polityki, ponieważ okazało się, że ambicje Polaków sięgają daleko poza rolę wiernych polskich poddanych króla pruskiego. Po roku 1830 rozpoczęto działania mające na celu najpierw depolonizację, a następnie germanizację szlachty polskiej. Nie zwracano przy tym uwagi na

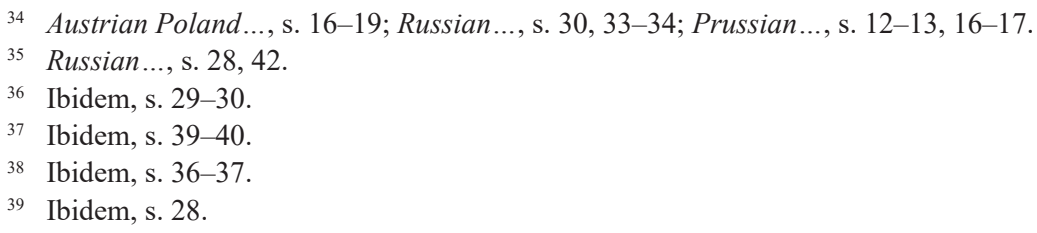


pozostałe warstwy, zakładając, że wzorem szlachty przyjmą kulturę niemiecką. Do roku 1848 działania te miały jednak ograniczony charakter, ponieważ wśród części polityków pruskich nadal obecne było przekonanie, że możliwe jest pozyskanie szlachty i pozostałych warstw społeczeństwa polskiego dla państwa pruskiego. Momentem przełomowym, kiedy politycy pruscy zrozumieli, że jest to niemożliwe i że Polacy będą dążyli do autonomii, a jeśli tylko pojawi się możliwość - do niepodległości, była Wiosna Ludów. Jej konsekwencje wykraczały poza sferę polityki, prowadząc do sytuacji, w której „żywioły polski i niemiecki wyraźnie i ostatecznie stanęły przeciw sobie" ${ }^{40}$. Konflikt został więc przeniesiony z relacji między rządem a mniejszością narodową na relacje między narodami. Odtąd element ten był stale obecny, przybierając na znaczeniu wraz z upływem czasu i dalszym zaostrzaniem polityki wobec Polaków. Nawet poparcie dla Polaków przez Partię Centrum w parlamencie Rzeszy zostało określone jako „bardzo wątpliwe”, to samo dotyczyło też większości niemieckich socjalistów. Między obydwoma narodami narastała wrogość, która znajdowała wyraz także w życiu codziennym ${ }^{41}$.

Do roku 1870 kurs wobec Polaków nie uległ widocznym zmianom ze względu na zaangażowanie zewnętrzne Prus. Po zjednoczeniu Niemiec sytuacja uległa gwałtownemu pogorszeniu. W zeszycie szczegółowo przedstawiono działania władz pruskich, na czele z Bismarckiem, nie ograniczając ich jednak do tej jednej postaci. Omówiono nie tylko politykę Kulturkampf, ale także, szczegółowo biorąc pod uwagę charakter wydawnictwa, działania takich instytucji i organizacji, jak Komisja Kolonizacyjna czy Niemiecki Związek Marchii Wschodniej ${ }^{42}$. Wszystkie spotkały się z krytyką, ponieważ stanowiły zaprzeczenie zasad nowoczesnego państwa prawa, czerpiąc wzory z Rosji: „metody, którymi się posługiwał [rząd pruski] stopniowo były coraz bardziej bezwzględne, znajdując odpowiednik wśród państw europejskich tylko w działaniach rządu carskiego"43. Działania okazały się też całkowicie nieskuteczne. Autor zeszytu uznał Kulturkampf za największy błąd w całej karierze politycznej Bismarcka ${ }^{44}$. Zwrócił też uwagę na aktywność Polaków, między innymi na działalność takich instytucji i organizacji, jak Bank Ziemski, Związek Ziemian, czy też na ruch spółdzielczy, ale i na spontaniczne protesty, w tym strajk dzieci z Wrześni w 1901 roku czy strajk szkolny w latach 1906-190745. Polityka władz pruskich przypominała sposób, w jaki biali kolonizatorzy traktowali tubylców w Afryce, nie stosunki między narodami europejskimi: „Polska prowincja Prus stanowi przykład jak władze pruskie traktowały obcą ludność, wcieloną wbrew swej woli [w skład tego państwa] i reakcję tej ludności na obce panowanie"46.

Z identyczną oceną spotkały się działania władz wobec Polaków w prowincjach Prusy Zachodnie i Prusy Wschodnie. Poświęcono im mniej niż dwie strony tekstu,

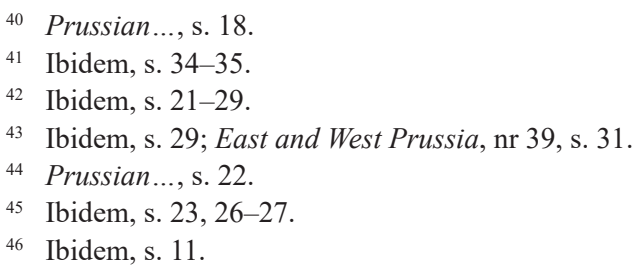


stwierdzając, że polityka pruska „polegała w dużym stopniu na atakach rządu pruskiego wobec polskich poddanych na polu religii, gospodarki, edukacji i polityki, tak jak to przedstawiono w zeszycie Pruska Polska" ${ }^{\text {"47 }}$. Efekty były takie same i prowadziły do wzmocnienia polskiej świadomości narodowej i rozwoju cywilizacyjnego Polaków ${ }^{48}$. Liczną obecność Polaków dostrzeżono w jeszcze jednej prowincji Prus, na Górnym Śląsku. O polityce władz wobec nich pisano niewiele, ograniczając się do stwierdzenia, że od 1873 roku próbują one w brutalny sposób zastąpić język polski językiem niemieckim ${ }^{49}$.

Odmiennie ułożyła się polityka władz austriackich. Po roku 1815 nie podjęły one próby pozyskania szlachty, uznając, że Galicja powinna być rządzona z Wiednia. Zaczęto zmierzać do osłabienia szlachty, wykorzystując w tym celu konflikt między wsią a dworem. Działaniom władz austriackich, centralnych i lokalnych przypisano rabację, choć równocześnie stwierdzono, że nie doszłoby do niej, gdyby nie postawa szlachty wobec żądań chłopskich ${ }^{50}$. Innym celem Wiednia było pozbawienie Polaków resztek niezależności. Zdaniem autora zeszytu władze austriackie, wiedząc o przygotowaniach do powstania w 1846 roku, dołożyły starań, aby doszło do jego wybuchu, wykorzystując je do likwidacji Rzeczpospolitej Krakowskiej. W tym samym jednak czasie, podobnie jak w przypadku pozostałych zaborców ze względu na problemy wewnętrzne i zewnętrzne, Wiedeń rozpoczął serię ustępstw, które doprowadziły do autonomii Galicji. Ocena autonomii dokonana przez autora zeszytu nie była jednoznaczna. Autonomia sprzyjała rozwojowi Polaków w dziedzinie kultury i nauki oraz - dzięki polskiej kontroli nad szkolnictwem - upowszechnieniu polskiej świadomości narodowej wśród dużej części mieszczaństwa i chłopów. Jednocześnie autonomia doprowadziła do pojawienia się znacznych różnic między Polakami mieszkającymi w Galicji a tymi, którzy mieszkali w „pruskiej” czy „rosyjskiej Polsce".

Działania władz rosyjskich i pruskich przyniosły rezultaty odwrotne do zamierzonych. Osłabienie pozycji szlachty nie doprowadziło do zaniku narodu polskiego, lecz do jego wzmocnienia. Władze były przekonane, że bez warstwy przywódczej chłopi szybko ulegną germanizacji bądź rusyfikacji. Nie doceniły znaczenia różnic kulturowych, przede wszystkim religijnych, między katolickimi chłopami a protestancką bądź prawosławną władzą. Poważnym błędem była wroga polityka wobec Kościołów rzymskokatolickiego i unickiego, co w przypadku pierwszego dało Polakom potężnego i dobrze zorganizowanego sojusznika. Walka z Kościołem przyniosła wyjątkowo niekorzystne dla władz skutki w „pruskiej Polsce”, gdzie, zdaniem autora zeszytu, do rozpoczęcia Kulturkampf większość chłopów pozostawała neutralna, jeśli nie przychylna, wobec działań pruskich. Uderzenie w religię i język polski zmusiły chłopów do opowiedzenia się po jednej ze stron, a ze względów religijnych i kulturowych była nią strona polska ${ }^{51}$. Wzrostowi świadomości narodowej sprzyjały zmiany

\footnotetext{
47 East and West Prussia, s. 30.

48 Ibidem, s. 31-32.

49 Upper Silesia, s. 7.

50 Austrian Poland..., s. 16-17.

51 Prussian..., s. 24.
} 
gospodarcze i będące ich rezultatem zmiany społeczne. Dzięki uwłaszczeniu chłopi stopniowo zyskiwali świadomość obywatelską, a rozwój przemysłu doprowadził do pojawienia się nowej klasy, robotników, i do rozwoju miast. Procesy te zbiegły się w czasie z deklasacją dużej części szlachty, która przesiedliła się do miast, przenosząc tam swoją kulturę, w tym poczucie polskości. W rezultacie od połowy XIX wieku zaczęła się kształtować polska klasa średnia, która dla władz zaborczych okazała się znacznie trudniejszym przeciwnikiem niż szlachta. Ważną cechą nowoczesnego społeczeństwa polskiego, która ułatwiała zachowanie i rozwój świadomości narodowej, był wysoki stopień samoorganizacji. W „,pruskiej Polsce” było to szczególnie widoczne w ruchu spółdzielczym, natomiast w „rosyjskiej Polsce” - w powstaniu i rozwoju partii politycznych. Świadomość i solidaryzm narodowy były tak silne, że pokonywały różnice polityczne czy religijne. W Królestwie, mimo znacznych różnic między partiami, wszystkie miały zbliżone poglądy na temat granic niepodległego państwa polskiego. W przypadku partii prawicowych i centrowych oznaczało to powrót do granic przedrozbiorowych z włączeniem Litwy, Białorusi i dużej części Ukrainy. W przypadku partii lewicowych, ugrupowań chłopskich i prawego skrzydła Polskiej Partii Socjalistycznej celem była „tylko” dobrowolna unia między Polską i Litwą, przez którą Polacy rozumieli Litwę historyczną, nie etnograficzną ${ }^{52}$. Na ziemiach wchodzących w skład państwa pruskiego podziały narodowe miały równie wielkie znaczenie - zdaniem autora zeszytu: „kwestia narodowa określa[ła] całość ludzkiego życia" ${ }^{53}$. W rezultacie tych zmian powstał nowoczesny naród polski, który obejmował wszystkie części społeczeństwa, a w którym czołową rolę odgrywała klasa średnia złożona z inteligencji, duchowieństwa, zamożnego mieszczaństwa i chłopstwa. Jego nowoczesny charakter miał się wyrażać również w odrzuceniu tego, co w jednym z zeszytów określono jako naiwną wiarę szlachty rozpoczynającej powstanie styczniowe w ,abstrakcyjną słuszność ich [Polaków] sprawy”54.

Większość tych zmian była ograniczona do ziem zaboru pruskiego oraz „rosyjskiej Polski”. W Galicji autonomia pozwoliła szlachcie zachować dominującą pozycję, konserwując podziały społeczne. W niedużym tylko stopniu podważyło je uwłaszczenie chłopów oraz rozwój przemysłu - ten ostatni ze względu na postawę polskich elit politycznych postępował znacznie wolniej niż w „pruskiej” czy „,rosyjskiej Polsce". Autonomia, w połączeniu z wielonarodowym charakterem wschodniej części Galicji, doprowadziła do jeszcze jednej ważnej różnicy. W przeciwieństwie do „rosyjskiej” i „pruskiej Polski”, gdzie Polacy byli narodem prześladowanym, w Galicji występowali w stosunku do ludności ukraińskiej jako naród uciskający ${ }^{55}$. Zdaniem autora zeszytu pogarszające się z polskiej winy relacje z Ukraińcami stały się „najważniejszym problemem politycznym Galicji”s6.

\footnotetext{
52 Russian..., s. 40, 53, 60.

53 Prussian..., s. 34.

54 Russian..., s. 34.

55 W zeszytach zamiennie używano określeń Ukraińcy” („Ukrainians”), „Małorosjanie” („Little Russians”) oraz „Rusini” („Ruthenians”). Zob. Hungarian..., s. 6-7; The Ukraine, s. 8-9, s. 72; Russian..., s. 19, 23; Austrian Poland..., s. 9.

56 Austrian Poland..., s. 21, 23, 25-32.
} 
O historii narodu polskiego pisano również na obszarach, które znalazły się poza Królestwem Kongresowym, Galicją i ziemiami zagarniętym przez Prusy w roku 1815. Informacje na ich temat ograniczały się jednak do stwierdzeń, że Polacy najczęściej wchodzą w skład warstw uprzywilejowanych, pozostając w konflikcie społecznym i ekonomicznym z ludnością niepolską ${ }^{57}$. Wyjątek stanowił „austriacki Śląsk”, gdzie Polacy, którzy zachowywali większość w jego wschodniej części, mieszkali głównie na wsi i tworzyli proletariat miejski, znajdując się pod dominacją niemiecką. Ich położeniu w całym okresie 1815-1914 poświęcono jednak zaledwie kilka zdań, stwierdzając, że zachowali silną tożsamość narodową ${ }^{58}$.

Znacznie szerzej omówiono sytuację Polaków na Litwie. Na początku XIX wieku stanowili warstwę uprzywilejowaną w stosunku do ludności miejscowej ${ }^{59}$, ale - podobnie jak w Królestwie Polskim - stali się ofiarą polityki caratu, i to jeszcze przed rokiem 1831. Autor zeszytu wspomniał między innymi o aktywności Nikołaja Nowosilcowa $\mathrm{w}$ Wilnie ${ }^{60}$. Po powstaniu listopadowym represje, które przedstawiono w szczegółowy sposób, uległy nasileniu. Władze rosyjskie uznały, że po pozbawieniu szlachty polskiej dominującej pozycji możliwa będzie pełna rusyfikacja całej ludności zamieszkującej Litwę. Podobnie jak w Królestwie Kongresowym działania te przyniosły efekt odwrotny do zamierzonego, $\mathrm{z}$ tą jednak różnicą, że miejsca szlachty jako warstwy przywódczej nie zajęła polska klasa średnia, lecz litewska inteligencja. Głosiła ona hasła odrodzenia narodowego i niepodległości Litwy, przyjmując antyrosyjskie i antypolskie stanowisko. Doprowadziło to do konfliktu z Polakami ${ }^{61}$, co wskazywało na szerszy problem. Przebudzenie czy odrodzenie narodowe w XIX i na początku XX wieku nie ograniczało się jedynie do Polaków, doświadczyły tego też inne narody - obok Litwinów przede wszystkim Ukraińcy. Stawiało to pod znakiem zapytania nie tylko stosunki między nimi a Polakami, ale także granice państwa polskiego ${ }^{62}$. Odradzające się państwo polskie znajdowało się nie tylko w nowej przestrzeni politycznej, która była następstwem wojny światowej i rewolucji, ale też w nowej sytuacji związanej z pojawieniem się i rozwojem nowoczesnych nacjonalizmów.

Przedstawiając historię Polaków w okresie 1815-1914, uwagę skupiono na tych zagadnieniach, które i dzisiaj znajdują się w centrum zainteresowania badaczy: na polityce władz państw zaborczych wobec Polaków i kształtowaniu się nowoczesnego narodu polskiego. Dobrze świadczy o autorach zeszytów, że potrafili wybrać elementy, które w dłuższej perspektywie okazały się najważniejsze, choć jednocześnie można mieć uwagi do ograniczonego zestawu poruszanych zagadnień. Warto jednak pamiętać, że były to wykłady historii Polski dla polityków, nie dla badaczy przeszłości, polityków przyzwyczajonych do tego, że nie istnieje niepodległa Polska, i dla których

57 Courland, Livonia and Esthonia, nr 50 s. 10; Bessarabia, s. 7; Bukovina, s. 8; Hungarian ..., s. 7; The Ukraine, s. 8-9, 49.

58 Austrian Silesia, s. 23.

59 Russian..., s. 41.

60 Ibidem, s. 43.

${ }^{61}$ Ibidem, s. 21, 41-48.

62 Ibidem, s. 59-62; The Ukraine..., s. 55-57. 
sprawa polska była jednym z wielu problemów do rozwiązania. Dzieje narodu polskiego opisano z jego perspektywy, nie z perspektywy państw zaborczych. Nie mamy do czynienia z opowieścią o pruskiej czy niemieckiej misji kulturalnej na zacofanym Wschodzie, ale o polityce represji wobec Polaków i ich reakcji na tę politykę. Podobnie było w przypadku zaboru rosyjskiego. Zdaniem autorów zeszytów naród polski wyszedł z tej próby zwycięsko. Nie tylko pokazał, jak mniejszość narodowa może skutecznie przeciwstawiać się działaniom tak potężnych państw jak Prusy czy Rosja, manifestował nieustanne dążenie do odbudowy własnego państwa, ale też, dzięki zmianom wewnętrznym, udowodnił zdolność do samodzielnego kierowania swoimi sprawami. Idea odbudowy państwa polskiego zyskała w ten sposób uzasadnienie, które nie ograniczało się do wskazania na niesprawiedliwość związaną z rozbiorami Polski czy też na „abstrakcyjną słuszność ich [Polaków] sprawy”. Polacy zasłużyli na niepodległy byt dzięki swojemu wysiłkowi modernizacyjnemu. Wyjątkiem była sytuacja w Galicji, gdzie procesy te były znacznie słabsze. Autor zeszytu Austriacka Polska nie negował jednak w ten sposób zasadności dążeń niepodległościowych, wskazywał raczej na niebezpieczeństwa dla odrodzonego państwa polskiego wynikające z zakonserwowania struktury społecznej z czasów przedrozbiorowych.

Takie obawy łatwo uznać za wyolbrzymione, ale wskazują one na szerszy problem. Podobnie jak w przypadku materiałów dotyczących Polski przedrozbiorowej autorom zeszytów obejmujących okres po roku 1815 towarzyszyło przekonanie, że znajomość historii pozwala formułować wnioski na przyszłość. W ich koncepcji niepodległej Polski najbardziej widoczne było przekonanie, że powinna ona zrezygnować z pomysłów odtworzenia I Rzeczpospolitej w jej kształcie terytorialnym czy społeczno-politycznym. W pierwszej kwestii posługiwano się zasadą etnograficzną, uznając, że w skład niepodległej Polski powinny wchodzić te ziemie, które są zdominowane liczebnie przez Polaków. W przypadku granicy z Niemcami oznaczało to włączenie do Polski całej „pruskiej Polski”, Prus Zachodnich i większej części Górnego Śląska, w której znajdowały się główne zasoby węgla ${ }^{63}$. W jednym z zeszytów postulowano również przyłączenie do Polski Gdańska. W tym wypadku nie kierowano się sytuacją narodowościową. Niemcy dominowali liczebnie w Gdańsku, ale bez polskiego zaplecza sytuacja gospodarcza miasta uległaby wyraźnemu pogorszeniu. Jedyną szansą na jego rozwój był związek z Polskąą . Bardziej skomplikowana była kwestia granicy na wschodzie. Plany odbudowy Rzeczpospolitej w granicach z 1772 roku czy federacji polsko-litewskiej odrzucono. Pojawiły się nawet oskarżenia o „polski imperializm”, który - gdyby zrealizowano plan w postaci przyłączenia do Polski Litwy historycznej bądź federacji polsko-litewskiej - stanowiłby „ciągłe zagrożenie dla pokoju Polski i Europy" z powodu ryzyka konfliktu między Polską a Rosją bez względu na to, kto sprawowałby władzę w tej ostatniej ${ }^{65}$. Polska granica etniczna przebiegała wzdłuż Bugu i tam Polska powinna się kończyć. Podobnie było ze wschodnią częścią Galicji, która ze względu na przewagę ludności ukraińskiej

\footnotetext{
${ }^{63}$ Prussian..., s. 36; Upper Silesia ..., s. 41-42.

${ }^{64}$ East and West Prussia, s. 43.

${ }_{65}$ Russian..., s. 60.
} 
powinna znaleźć się poza granicami Polski. Wpływ na taką koncepcję granic miała nie tylko zasada etnograficzna, ale też, paradoksalnie, historia narodu polskiego w latach 1815-1914. Pokazała ona bowiem, że w sytuacji odrodzenia narodowego nie jest możliwe włączenie dobrze zorganizowanej mniejszości w skład narodu dominującego. Skoro nie zdołali tego uczynić Niemcy i Rosjanie w stosunku do Polaków, Polacy nie byliby w stanie tego osiągnąć wobec Litwinów i Ukraińców.

Odrodzona Polska powinna również zerwać z dziedzictwem społecznym i politycznym I Rzeczpospolitej. Naród polski przetrwał politykę represji nie dzięki postawie szlachty (ta kolejnymi powstaniami i niechęcią do zmian pogarszała sytuację), ale dzięki pojawieniu się klasy średniej i przejęciu przez nią roli przywódczej. Wzorem dla społeczeństwa niepodległej Polski powinny być społeczeństwa zachodniej części Europy. Autorzy nie pozostawili Polakom miejsca na odrębności wynikające z ich specyficznej historii czy kultury. Uznali, że istnieje „właściwa” forma patriotyzmu, która w głównej mierze jest wytworem bieżącej sytuacji społecznej i ekonomicznej. Polski patriotyzm powinien być dostosowany do czasów, w których troska o naród i państwo wyrażała się pracą na rzecz rozwoju gospodarczego i cywilizacyjnego. Polacy nie powinni kierować się „romantycznym patriotyzmem”, który, zdaniem autorów, nawiązywał do bezpowrotnie minionych czasów. Najlepiej „nowoczesny patriotyzm" mieli rozumieć ci Polacy, którzy żyli pod panowaniem pruskim, a bez których „państwo polskie nie może być odbudowane ani pod względem narodowym ani gospodarczym... i którzy stanowią najlepiej zorganizowaną społeczność wiejską i najbardziej rozwiniętą część klasy średniej w Polsce"

Łatwo dostrzec podobieństwa między powyższymi poglądami a opiniami zawartymi w zeszycie Polska: Ogólny zarys historii 1569-1815. Z dużym prawdopodobieństwem można przyjąć, że jego autor, wspomniany już profesor Oman, przygotował również zeszyty Pruska Polska, Prusy Wschodnie i Zachodnie, a także Górny Ślask. Świadczyły o tym wykorzystana literatura, w której pojawiła się tylko jedna praca w języku polskim, oraz opinie na temat granicy zachodniej odrodzonego państwa polskiego, które odpowiadały poglądom wyrażonym przez Omana w innych opracowaniach ${ }^{67}$. Zeszyty Rosyjska Polska oraz Austriacka Polska zostały najprawdopodobniej opracowane przez Luisa Namiera. Wskazuje na to bogactwo wykorzystanej literatury w językach polskim, rosyjskim i ukraińskim; wśród przywołanych autorów znaleźli się Franciszek Bujak, Roman Dmowski, Mychajło Hruszewski i Wasilij Kluczewski. Przemawia za tym również sformułowanie „polski imperializm", które występowało w innych materiałach przygotowanych przez Namiera ${ }^{68}$. W zeszycie Austriacka Polska termin ten się nie pojawił, ale ocena była podobna, ponieważ Polacy w okresie autonomii mieli dyskryminować „Małorosjan” do tego stopnia, że ich położenie było gorsze niż we wcześniejszym okresie ${ }^{69}$. Opinia ta pokrywała się z poglądami wyrażanymi przez Namiera przy innych okazjach ${ }^{70}$. Także

\footnotetext{
66 Prussian..., s. 36.

${ }^{67}$ T. Piszczkowski, op. cit., s. 23-24, 79-80; M. Nowak-Kiełbikowa, op. cit., s. 59.

68 B. Rusin, op. cit., s. 102.

69 Austrian Poland, s. 28-29.

70 A. Cienciała, op. cit., s. 76.
} 
obliczenia w kluczowej sprawie liczebności poszczególnych narodów we wschodniej części Galicji w zeszycie Austriacka Polska wskazują na autorstwo Namiera ${ }^{71}$.

Zeszyty dostarczają solidnej wiedzy na temat historii Polski przedrozbiorowej oraz narodu polskiego w latach 1815-1914 w zakresie interesującym ich autorów. Stanowią też wyraźny krok do przodu w stosunku do opinii pojawiających się w brytyjskiej prasie na temat Polski, jej historii i współczesności w XIX wieku. Częsty był pogląd, że jakkolwiek rozbiory Polski stanowiły pogwałcenie prawa międzynarodowego, to w dużym stopniu były zawinione przez samych Polaków, którzy doprowadzili państwo do ruiny ciągłymi sporami politycznymi oraz prześladowaniami mniejszości religijnych ${ }^{72}$. Równie popularny był pogląd, że społeczeństwo polskie nadal było zdominowane przez szlachtę, która gnębiła pozostałe klasy, uniemożliwiając rozwój gospodarczy i społeczny. Do tego stopnia, że większość mieszkańców ziem polskich - tych, które ograniczano do „rosyjskiej Polski” - pozbawiona była świadomości narodowej ${ }^{73}$. Odbudowa niepodległej Polski - ze względu na postawę Polaków, którzy zamiast stawiać na rozwój cywilizacyjny, rozpoczynali skazane na klęskę powstania, wykazując brak zdolności do stworzenia sprawnych rządów, oraz ze względu na układ sił między mocarstwami - była mrzonką ${ }^{74}$. Podobne stanowisko prezentowano także przez dużą część I wojny światowej, kiedy to w prasie brytyjskiej i wśród polityków brytyjskich dominował pogląd, że sprawa polska jest wewnętrzną sprawą brytyjskiego sojusznika, czyli Rosji ${ }^{75}$. Zmiana nastąpiła dopiero na początku roku 1918, wraz z dramatycznymi wydarzeniami w Rosji, które oznaczały załamanie dotychczasowego porządku w środkowej i wschodniej części Europy ${ }^{76}$.

Zasób informacji zawarty w zeszytach pozwala zanegować popularny wśród polskich polityków i historyków pogląd o nieznajomości dziejów i spraw Polski, a szerzej - Europy Środkowej i Wschodniej, przez stronę brytyjską ${ }^{77}$. Poziom wiedzy ekspertów należy ocenić jako w pełni zadowalający i do pewnego stopnia wiedza ta miała wpływ na stanowisko delegacji brytyjskiej w Paryżu. W memoriale przygotowanym

71 J. Namier, op. cit., s. 335; T. P iszczkow ski, op. cit., s. 78. Na temat oceny poglądów Namiera w sprawie polskiej dokonanej przez Omana zob. J. Paje w ski, Dwie zachodnie opinie wobec koncepcji granic państwa polskiego $(1917,1919)$, „Studia Historica Slavo-Germanica” 1977, t. 6, s. 145-147.

72 I. Sakowicz-Tebinka, Imperium..., s. 172-173, 197, 235.

73 Ibidem, s. 171-173, 182, 207.

74 Ibidem, s. 171, 178, 186, 187, 212, 222-223.

75 J. Pajewski, Wokót sprawy polskiej. Paryż - Lozanna - Londyn 1914-1918, Poznań 1970, s. 170-173, 193; J. Złotkiewicz-Kłębukowska, Prasa brytyjska o Polsce w ostatnich miesiacach caratu, „Annales Universitatis Mariae Curie-Skłodowska” 2002, vol. LVII, s. 199-208.

76 Por. M. B aumgart, Wielka Brytania a odbudowa Polski 1914-1923, Szczecin 1990, s. 45-49.

77 T. Komarnicki, Rebirth of the Polish Republic. A Study in the Diplomatic History of Europe, 1914-1920, Melbourne 1957, s. 141, 320; A. Cienciała, Polityka..., s. 83, 89-93; M. Nowak-Kiełbikowa, Polska-Wielka Brytania..., s. 62; N. Davies, Lloyd George i Polska 1919-1920, Gdańsk 2000, s. 10, 12, 19; M. B a umg art, Wielka Brytania a odrodzona Polska (1918-1933), Szczecin 1985, s. 64-65; B. Rusin, op. cit., s. 96, 112; A. Nowak, op. cit., s. 64-65, 217-218, 273-274, 290 292, 294, 307, 312, 317-318; 327-328, 351-353, 360, 409, 423, 444-445; T. Pudłocki, Ambasadorzy idei. Wkład intelektualistów w promowanie pozytywnego wizerunku Polski w Wielkiej Brytanii w latach 1918-1939, Kraków 2015, s. 33-37, 89; Polskie dokumenty dyplomatyczne 1919. Styczeń-maj, red. S. Dębski, Warszawa 2016, s. 123, 451, 887-888. 
w listopadzie 1918 roku pod kierownictwem Esme Howarda, będącym programem dla delegatów brytyjskich, przyjęto niektóre propozycje zawarte w przedstawionych materiałach. Dotyczyło to części granicy wschodniej, która na środkowym i południowym odcinku miała przebiegać wzdłuż Bugu i Sanu. Powtórzono również część propozycji dotyczących granicy zachodniej. Profesor Oman był zwolennikiem przyznania Polsce nie tylko „pruskiej Polski”, Prus Zachodnich, większej części Górnego Śląska, ale także zdominowanego przez Niemców Gdańska. W memoriale Howarda powtórzono jego opinie na temat ,pruskiej Polski” i Górnego Śląska, negując propozycje dotyczące Prus Zachodnich (Polska miała otrzymać tylko cztery powiaty) oraz Gdańska $^{78}$. Delegacja brytyjska podtrzymywała takie stanowisko do połowy marca 1919 roku, kiedy premier David Lloyd George zanegował je w części dotyczącej granicy zachodniej, odrzucając tym samym ustalenia ekspertów ${ }^{79}$. Najłatwiej tłumaczyć jego postawę brakiem wiedzy czy niechęcią do Polski. Obok słów, że w całej swojej historii Polacy nie zdołali wykazać „zdolności do trwałej samodzielności”, David Lloyd George zarzucał im, że „potrafią domagać się dla siebie więcej, aniżeli im prawnie przysługuje", w czym wspierali go inni politycy brytyjscy ${ }^{80}$. W trakcie posiedzenia Rady Czterech w obecności Ignacego Paderewskiego zdobył się na obraźliwe stwierdzenie, że „w czasie tych czterech czy pięciu lat wojny Polacy w istocie rzeczy walczyli przeciwko własnej wolności, o ile w ogóle walczyli”, podkreślając przy innej okazji, że Polska niepodległość zawdzięcza wyłącznie ofierze krwi żołnierzy alianckich, przeciwko którym Polacy walczyli „do ostatniej chwili wojny”81. Towarzyszyły temu mylenie hiszpańskiej prowincji Galicja z Galicją Wschodnią oraz pytania, czy istnieje różnica między językami polskim i ukraińskim ${ }^{82}$. Ten sam polityk jednak, gdy służyło to realizacji jego koncepcji, powoływał się na ustalenia ekspertów, zarówno w odniesieniu do zachodniej granicy Polski, jak i w sprawie Galicji Wschodniej ${ }^{83}$. Wskazuje to na instrumentalne traktowanie wiedzy, charakterystyczne dla polityków wszystkich czasów i miejsc. Wiedza miała wspierać brytyjską koncepcję ładu powojennego, tak jak widział ją premier. Nadrzędnym celem było zapewnienie bezpieczeństwa imperium brytyjskiemu, o czym dyplomaci polscy informowali Warszawę jeszcze przed konferencją pokojową ${ }^{84}$, a do tego w Europie niezbędne były

78 T. Piszczkowski, op. cit., s. 73-78; M. B aumgart, Wielka Brytania a odbudowa ..., s. 66-67.

79 M. Baumgart, Wielka Brytania a odbudowa..., s. 72-73, 76; Sprawy polskie na konferencji pokojowej w Paryżu w 1919 r., red. R. Bierzanek, J. Kukułka, t. I, Warszawa 1965, s.123, 125-128, 131-133, 272, 313-314; K. Lund green-Niels en, The Polish problem at the Paris Peace Conference: A study of the policies of the Great Powers and the Poles, 1918-1919, Odense 1979, s. 233-239; M. Mac Millan, Paris 1919, New York 2003, s. 195-198.

80 M. Baumgart, Wielka Brytania a odbudowa..., s. 73; Sprawy polskie na konferencji pokojowej w Paryżu w 1919 r., red. R. Bierzanek, J. Kukułka, t. II, Warszawa 1967, s. 272; M. Mac Millan, op. cit., s. 215, 220.

${ }_{81}$ Sprawy polskie..., t. I, s. 218; Sprawy polskie..., t. II, s. 59.

82 J. Pisuliński, Nie tylko Petlura. Kwestia ukraińska w polskiej polityce zagranicznej w latach 1918-1923, Wrocław 2004, s. 75; Sprawy polskie..., t. II, s. 320; M. Mac Millan, op. cit., s. 42.

83 Sprawy polskie..., t. II, s. 35, 272, 319; M. Mac Millan, op. cit., s. 39-40.

${ }^{84}$ Polskie dokumenty dyplomatyczne 1918. Listopad-grudzień, red. S. Dębski, Warszawa 2008, s. 306-307. 
dwa elementy. Pierwszy to zapobieżenie następnemu konfliktowi zbrojnemu, czemu w Europie Środkowej i Wschodniej miało służyć tworzenie państw oparte na kryterium etnograficznym ${ }^{85}$. Jakiekolwiek próby zmierzające w przeciwnym kierunku były traktowane jako polityka ,imperialistyczna"86.; odnosiło się to nie tylko do premiera Davida Lloyda George'a, ale także do przychylnego Polsce posła w Warszawie Horacego Rumbolda. Stanowisko to odpowiadało poglądom wyrażonym przez Namiera. Drugi element to przywrócenie równowagi sił, zachwianej zdaniem polityków brytyjskich na korzyść Francji ${ }^{87}$. Wykluczało to nadmierne osłabienie Niemiec, które dążąc do rewizji układu pokojowego, mogły jeszcze nawiązać współpracę z Rosją bolszewicką ${ }^{88}$. Stąd niechętny stosunek Londynu nie tylko wobec polskiej koncepcji granicy zachodniej, wyrażany zarówno przed 11 listopada 1918 roku, jak i w trakcie konferencji pokojowej, ale także w stosunku do propozycji dotyczących kształtu terytorialnego odrodzonej Polski, przedstawianych przez jej przedstawicieli ${ }^{89}$. W obliczu takich celów argumentacja historyczna, po którą chętnie sięgali polscy polity$\mathrm{cy}^{90}$, często nie była brana pod uwagę przez stronę brytyjską. Nie oznacza to, że była całkowicie bezużyteczna. Argumentacja historyczna była pomijana wtedy, gdy było to wygodne, szczególnie przy ustalaniu granic państwa polskiego. Równocześnie jednak stanowiła element przemawiający na rzecz odbudowy niepodległego państwa polskiego ${ }^{91}$, choć $\mathrm{w}$ innym kształcie terytorialnym, niż zakładali polscy politycy.

\section{BIBLIOGRAFIA}

Araminski S., Historie de la Revolution Polonaise (1772 a 1864), Paris 1864.

Baumgart M., Wielka Brytania a odrodzona Polska (1918-1933), Szczecin 1985.

Baumgart M., Wielka Brytania a odbudowa Polski 1914-1923, Szczecin 1990.

Butterfield H., The Whig Interpretation of History, London 1931.

Chwalba A., Historia Polski 1795-1918, Kraków 2000.

Cienciała A., Polityka brytyjska wobec odrodzenia Polski, 1914-1918, „Zeszyty Historyczne" 1969, z. 16, s. 67-94.

Davies N., Lloyd George i Polska 1919-1920, Gdańsk 2000.

85 T. Komarnicki, op. cit., s. 213, 228; A. Cienciała, op. cit., s. 79-80; T. Piszczkowski, op. cit., s. 41, 61; Sprawy polskie..., t. I, s. 108-109.

${ }^{86}$ Por. Documents on British Foreign Policy 1919-1939, ed. E.L. Woodward, R. Butler, $1^{\text {st }}$ ser., Vol. III, London 1949, s. 766; Sprawy polskie..., t. I, s. 218-220; Sprawy polskie ..., t. II, s. 324.

87 M. MacMillan, op. cit., s. 42.

88 M. Baumgart, Wielka Brytania a odbudowa..., s. 61-65, 72-73, 78, 104, 107; J. Pajewski, Odbudowa państwa polskiego 1914-1918, Poznań 2005, s. 220-221; Sprawy polskie..., t. I, s. 134-136, $185-186$.

${ }^{89}$ K. Lundgreen-Nielsen, op. cit., s. 60-61, 241-242, 244-245, 364-368; M. MacMillan, op. cit., s. 211; Polskie dokumenty dyplomatyczne 1919 ..., s. 889-890.

90 Documents on British..., s. 352; Sprawy polskie..., t. I, s. 51-52, 54-55, 64-66, 72-77, 105-107, 203-204, 207.

91 M. MacMillan, op. cit., s. 212. 
Documents on British Foreign Policy 1919-1939, ed. E.L. Woodward, R. Butler, fisrt series, vol. III, London 1949.

Goldstein E., Winning the Peace. British Diplomatic Strategy, Peace Planning and the Paris Peace Conference, 1916-1920, Oxford 1991.

Handbooks prepared under the Direction of the Historical Section of the Foreign Office, H.M. Stationery Office, London 1920: Austria, Hungary, Foreign Policy of Austria-Hungary, $\mathrm{nr}$ 1; Austrian Silesia, nr 4; Bukovina, nr 5; Hungarian Ruthenia, nr 7; Turkey in Europe, nr 16; Belgium, nr 26; East and West Prussia, nr 39; Upper Silesia, nr 40; Poland: General Sketch of History 1569-1815, nr 43; Russian Poland, Lithuania and White Russia, nr 44; Prussian Poland, nr 45; Austrian Poland, nr 46; Poland: History 1571-1774, nr 49 (pierwotna numeracja); Poland: 1774-1815, nr 50 (pierwotna numeracja); Courland, Livonia and Esthonia, nr 50; The Ukraine, nr 52; Mongolia, nr 68; Persian Gulf, nr 76; The Freedom of the Seas (Historical), nr 148; International Rivers, nr 149; International Congresses and Conferences, nr 151; The Congress of Vienna, nr 153; Schemes for maintaining General Peace, nr 160; President Wilson's Policy, nr 161; oraz mapy (bez numerów zeszytów): Maps of Austria-Hungary; Maps of the Balkan Peninsula; Maps of Poland; Ethnographical Maps of Central and South-Eastern Europe and Western Asia.

Komarnicki T., Rebirth of the Polish Republic. A Study in the Diplomatic History of Europe, 1914-1920, Melbourne 1957.

Lelewel J., Historie de Pologne, 2 Vols, Paris 1844.

Lewiński-Korwin E.H., The Political History of Poland, New York 1917.

Lundgreen-Nielsen K., The Polish Problem at the Paris Peace Conference: A Study of the Policies of the Great Powers and the Poles, 1918-1919, Odense 1979.

MacNillan M., Paris 1919, New York 2003.

Namier J., Lewis Namier: A Biography, London 1971.

Nowak A., Pierwsza zdrada Zachodu. 1920 - zapomniany appeasement, Kraków 2015.

Nowak-Kiełbikowa M., Polska-Wielka Brytania w latach 1918-1923. Kształtowanie się stosunków politycznych, Warszawa 1975.

Pajewski J., Dwie zachodnie opinie wokót koncepcji granic państwa polskiego (1917, 1919), „Studia Historica Slavo-Germanica” 1977, t. 6, s. 139-156.

Pajewski J., Odbudowa państwa polskiego 1914-1918, Poznań 2005.

Pajewski J. Wokół sprawy polskiej. Paryż - Lozanna - Londyn 1914 - 1918, Poznań 1970.

Pisuliński J., Nie tylko Petlura. Kwestia ukraińska w polskiej polityce zagranicznej w latach 1918-1923, Wrocław 2004.

Piszczkowski T., Anglia a Polska 1914-1939 w świetle dokumentów brytyjskich, Londyn 1975.

Poland's Case for Independence, London 1916.

Polskie dokumenty dyplomatyczne 1918. Listopad-grudzień, red. S. Dębski, Warszawa 2008.

Polskie dokumenty dyplomatyczne 1919. Styczeń-maj, red. S. Dębski, Warszawa 2016.

Pudłocki T., Ambasadorzy idei. Wkład intelektualistów w promowanie pozytywnego wizerunku Polski w Wielkiej Brytanii w latach 1918-1939, Kraków 2015,

Rusin B., Lewis Namier a kwestia ,linii Curzona” i kształtowania się polskiej granicy wschodniej po I wojnie światowej, „Studia z Dziejów Rosji i Europy Środkowo-Wschodniej” 2013, t. 48, s. 95-116.

Sakowicz-Tebinka I., Imperium barbarzyńców. Rosja Aleksandra II w brytyjskich opiniach prasowych, Gdańsk 2010.

Shaw-Lefevre G., The Partitions of Poland, London 1915. 
Sprawy polskie na konferencji pokojowej w Paryżu w 1919 r., red. R. Bierzanek, J. Kukułka, t. I, Warszawa 1965.

Sprawy polskie na konferencji pokojowej w Paryżu w 1919 r., red. R. Bierzanek, J. Kukułka, t. II, Warszawa 1967.

Starczewski T., L'Europe et la Pologne, Paris 1913.

The Cambridge Modern History, Vols. V, VIII, X.

Zięba A., Historyk jako produkt historii, czyli o tym, jak Ludwik Bernstein przeksztatcat sie w Lewisa Namiera [w:] Historyk i historia. Studia dedykowane pamięci Prof. Mirosława Frančicia, red. A. Walaszek, K. Zamorski, Kraków 2005, s. 149-174.

Złotkiewicz-Kłębukowska J., Prasa brytyjska o Polsce w ostatnich miesiacach caratu, „Annales Universitatis Mariae Curie-Skłodowska” 2002, vol. LVII, s. 197-208. 